\title{
Exploring Past Myths through Giambattista Vico and Jyotiba Phule
}

\section{Aparna Devare*}

\begin{abstract}
In this article, I examine the writings of the 18th-century Italian thinker Giambattista Vico and the 19th-century Indian thinker/social reformer Jyotiba Phule about myths, temporality, and the past. Both these thinkers turned to historicising myths in order to engage with debates in the present. Both viewed myths as reflecting social relations of power and domination, and sought to understand their material realities, emphasising human agency, collective change, and the social construction of language and practices. Both pointed to the limits of history, albeit in different ways: Vico by introducing the notion of providence, and Phule by rewriting the myths he had rationalised, using the same mythological figures, in order to intervene in the politics of the present from a marginal perspective (that of being low-caste). I juxtapose these two disparate thinkers in terms of their similarities in historicising myths, and analyse why Phule goes further than Vico in exceeding the boundaries of history. I argue that Phule's cultural context allowed him to return to myths more easily than Vico, although the latter revered them as well.
\end{abstract}

Keywords: Vico; Phule; Myths; Hinduism; History.

\section{Introduction}

Giambattista Vico (1668-1744) ${ }^{1}$ is widely regarded as one of the first modern historians because he undertook a rational, contextual study of ancient Greek and Roman myths at a time when sacral and classical conceptions of temporality were still prevalent. In the European Christian world of the 1600s, ancient myths were primarily viewed as legends, allegories and stories, and were yet to become objects of historical study. Vico changed the way in which historians understood myths by placing them in their historical contexts. Rather than viewing myths as eternal stories applicable to all times and places, Vico saw them as reflecting the realities of the societies in which they were created. As Patrick Hutton (1996: 540) has noted, Vico was one of the first modern historians to 'emphasize the relativity of the human condition to historical context. Indeed, it was his great contribution to the European Enlightenment.'

Vico's new approach to Greek and Roman myths, separating past and present through his emphasis on historical context and its materiality, did help to open the way to new

* University of Hyderabad, Hyderabad-TS, India; adev73@gmail.com. 
modes of historical thinking. As Isaiah Berlin (1980: 38) has noted, by criticising the notion of essential and fixed laws, highlighting historical contexts, and emphasising the need to understand origins and how humans develop through time by their own agency, Vico laid out the entire, embryonic, doctrine of historicism. This paved the way for later thinkers to further develop historicity and modern historiography as well as a range of philosophical ideas, such as Romanticism, Marxism, the notion of Verstehen, and critical theory. Some scholars have even classified Vico as a post-modernist (Fahey 2006; Lila 1993). Lila (1993: 38) refers to his political theory as 'anti-modern', while Avis (1986: 158) has called him a 'renegade Cartesian'. Both argue that Vico initiated the historicist school in Europe that centred on the notion of Verstehen, running from Herder through Dilthey to Collingwood. Others have argued that Vico initiated religious and cultural studies, social constructivism (Renger 2014: 42), and the genealogical method of thinking (Miner 2002). ${ }^{2}$ The historicity that Vico articulated in response to his contemporaries' ideas about essential human nature and fixed scientific laws provided ample insights for post-Cartesian critics, ranging from Marxists to post-modernists. His was a strong critique of Cartesian scientific certitudes (Luft 1996).

The Vichian view of myths as objects of historical study situated in a distinct historical context that could be viewed in totality (though an interrelated perspective on society, economy, culture, laws, and so on) affected other locales as well, including the nonwestern societies to which these ideas travelled via colonialism. In India, one of the first thinkers to rationalise and historicise local myths by placing them in the past was Jyotiba Phule, ${ }^{3}$ who lived in the mid-1800s and was deeply influenced by Western colonial ideas. When I first read Phule and his rationalisation of ancient Hindu myths, I was struck by the similarity between his approach and that of Vico, although there is no evidence that the former actually read the latter. Phule, like Vico, saw myths as reflecting the social reality of the times in which they were created rather than as stories (whether religious, moral, allegorical or entertaining), the prevailing view at the time. Unlike Vico, he then went on to write an alternate set of mythologies rooted in peasant cosmologies. Vico, despite his sensitivity to ancient myths and their beauty, and the fact that many of his ideas were still rooted in the classical traditions of Europe, could not view myths as anything but tales reflecting the peoples of a time gone by; rewriting them would be to re-inhabit them in ways that would not be conducive to the new ideas he was laying out, which assumed a separation of past and present by privileging historical context and the questioning of 'eternal' truths.

Following Vico's critique of ahistorical thought, many critical historians (including post-modernists) have grappled with this dilemma: since the past, including ancient myths, belong to a different historical context, how can these stories be made alive again in ways that collapse the past and present? History-writing, even when done in a reflexive way, with the historian calling it a narrative or a kind of myth, cannot become myth, for then it would no longer be history. In the course of his critique of the Cartesian fixities, including ideas of an eternal human nature, that undergirded many of the new ideas of his time, Vico provided historicity as an alternative that emphasised development, change, and process. In doing so, he introduced new notions of temporality that gave the past 
some unique characteristics that separated it from the present. In this view, the past was a time gone by that could be regarded either with scorn, as did those who believed in notions of progress, or a tinge of nostalgia and a sense of loss, as did Vico and others influenced by his thinking.

Mali (1992: 143) has made this point by suggesting that myths could only become objects of historical study when they were no longer living:

The myths of antiquity, well-known and long familiar, could become objects of scientific knowledge only after they had been defamiliarised to an audience which had always regarded them as natural. Because, as long as the Europeans were still too intimately close and loyal to these tales, they could not gain the necessary critical distance to examine them objectively; paradoxically it was only when they became more alienated from the classical myths that they could come to understand them better.

In other words, a greater critical understanding, or (as Vico put it) a 'new art of criticism' only became possible when these myths were relegated to the past in the form of history.

Even as Phule gave great importance to historicising the past, he exceeded historical temporality with greater ease than Vico. I argue that Phule was immersed in a cultural context that allowed him to do just that. Ideas of historicity were yet to make inroads into Indian society, and shared space with other temporalities and ways of viewing the past. Vico was responding to Locke, Hobbes, Grotius, Descartes, and various other philosophers who saw human nature as unchanging, fixed, and corresponding to the eternal laws in social contract, legal, and scientific theories. He strongly disagreed with their assumptions about human nature and society, believing that the social contract theorists were providing an ahistorical view of society rather than focusing on the origins and development of human nature and human institutions. Even if he was heavily influenced by the classical world view, Vico's criticism of these philosophers was not a reiteration of the classical doctrines, but rather an enunciation of new principles and methods for understanding humankind, which he saw as more rational and scientific.

For Vico, human societies had to be understood in the context of their historicity, establishing history, in the process, as the most legitimate and rational mode of viewing myths as well as the past more generally. As Avis (1986: 136) has noted: 'He was claiming that historical understanding is a form of cognition, a primary mode of perceiving the truth about reality, and one vastly superior to mathematics and the exact sciences. History would show the particularity and uniqueness of as well as the differences among cultures without being judgmental, and counter claims to absolute truths (Renger 2014: 49). Phule also turned to historicising ancient myths and legends in order to counter 'timeless' traditions, but ended up retelling these imaginative stories in new ways. While history can be said to be a form of story-telling, it has to follow certain conventions of 'evidence'. 
In this article, I juxtapose Vico and Phule. I acknowledge that Vico, even while enunciating new ideas of historicity, also exceeds the limits of history, but does not go as far as Phule in doing so. I argue that Phule could 'exceed' Vico in this respect because he lived in a cultural context, a field of ideas and practices, that had yet to be driven by 'sequential temporal relations' (Raghuramaraju 2011: 25), one in which multiple forms of temporality could coexist. As noted earlier, these temporalities became increasingly marginal to the European imagination, in which ideas of non-contemporaneity grew stronger through the discourse of history (Banerjee 2006: 6). Reading Phule as 'exceeding' Vico points to the limits of history, even in European critical discourse. This is an attempt, then, to 'provincialize Europe' (Chakrabarty), not just in geographic terms, but also in the course of opening up and exploring alternative ways of viewing past myths, thereby enriching the debate about history and temporality in general. Pointing to alternative temporalities is important as a form of 'decolonisation', since, as Walter Mignolo argues, categories such as history are always colonial in their suppression of difference. While recognising that this argument may amount to indulging in a kind of 'reverse orientalism', I do believe that the ideas of historicity which consigned ancient classical myths to the past had not made significant inroads into Phule's cultural milieu, and thus had to share space with other temporalities. Phule, despite his rationalism, was influenced by these alternative ideas.

I acknowledge that both Vico and Phule were complex figures who cannot necessarily be read as reflecting their cultures, as cultures themselves are complex and heterogeneous. Vico's stand against the dominant ideas of his time and his separation from the classicists in order to carve out his own unique space and voice makes this quite clear, as does Phule's attempt to separate himself from the Brahminical tradition, previous traditional lowercaste critiques rooted in sacrality, and the views of British missionaries, who influenced him heavily. The difference was that Vico would have been less enthusiastic about going back to an ahistorical, classicist reading of myths, because European society was clearly moving in a very different direction, whereas in Indian society these ideas had to coexist with others, and enjoyed less legitimacy.

There were alternative strands within European thought in which historicity remained tenuous until the $19^{\text {th }}$ century. This was especially so for marginal communities, like the Jews, who often lived with alternative traditions. Yosef Hayim Yerushalmi (1982) points out that Jews, much like Indians, were indifferent to historiography from the middle ages up to the $19^{\text {th }}$ century. Gabrielle Spiegel (2002) confirms that Jews in the medieval period drew heavily on memory through ritual and recital. Even post-Holocaust witnesses drew on what she calls 'durational time', which, unlike chronological time, did not and does not separate the past from the present.

Yerushalmi (1982) made a similar point when he observed that medieval Jews were indifferent to historiography, and that Jewish thinkers only took up this notion in the $19^{\text {th }}$ century. According to him, 'modern effort to reconstruct the Jewish past begins at a time that witnesses a sharp break in the continuity of Jewish living, and hence also an evergrowing decay of Jewish group memory... For the first time, history, not a sacred text, becomes the arbiter of Judaism' (Yerushalmi 1982: 86). Both Spiegel and Yerushalmi discuss the limits of modern historiography in Jewish remembrance of the past. Both point 
out that memory, unlike history, can bring the past to life and become part of a collective identity in ways that history cannot. Modern historiography, Spiegel (2002) has written, is based on a separation of past and present that memory tends to collapse. Yerushalmi (1982) talked about a loss of group memory among Jews, a void that cannot be filled by history. The language of 'loss' seems pervasive even among scholars such as Yerushalmi and Spiegel, who talk about marginal traditions that continue to exist in Europe involving alternative notions of temporality and the past, such as those based on memories.

In this article, I look at how both Vico and Phule historicised ancient myths and 'unmasked' them as stories reflecting social relations, especially those involving power and domination. Both emphasised the social constructedness of the past (to use a contemporary term), and saw humans as makers of history. They also shared a critical attitude towards the certitudes of their times. Vico was far more tolerant of the myths he was writing about, while Phule saw them as irrational and ignorant stories. And yet, Phule 'returns' to these 'irrational' myths as an alternative to history, with its purported separation of past and present. While Vico also explores the limits of history, via his ideas of cyclical time and the role of providence, Phule takes some of the figures from the ancient myths and writes countermyths about them, disregarding all attempts at historical or scientific objectivity - i.e., any formal rules of evidence upon which history is based. Vico also stresses the significant role of the imagination in constructing the past, and is not a 'scientific' historian in that sense, but maintains a distinction between 'history' and 'myth'. Myths may be beautiful, and worthy of admiration, but they reflect the imaginative and poetic capacities of humans; they cannot actually be true. As Mali (1992: 10) points out, Vico did not see his best-known work, The New Science (1725), as a new kind of myth (i.e., science as myth), but as a science of mythology. In the second section of this article, I will examine how both thinkers also limit history, with Phule going further than Vico in this regard.

\section{Historicising myths and legends}

As a professor of rhetoric, Vico was steeped in the classics, and heavily influenced by both Catholicism and Renaissance humanism. It was his reading of poetry, classical languages and classical literatures that influenced his enduring love affair with Greek and Roman myths. Like his classical predecessors, Vico upheld poetic wisdom, imagination, creativity, and holistic knowledge (Levine 1991). This is clearly reflected in his writings, especially in his reverence for myths as reflecting the higher poetic being of humans. He turned to myths precisely because of the scorn heaped upon it by his contemporaries as an irrational' and 'unscientific' source of knowledge, and tried to 'rehabilitate' it (Mali 1992). Vico drew this sensibility and love of poetic wisdom from the classicist traditions which, he believed, defined human beings. From traditional Catholicism, he brought a belief in the ultimate power of God and the limited power of humans to understand the world, especially its aspects they had not made, notably the natural world made by God.

Vico regarded the Protestant thinkers responsible for the new scientific ideas as arrogant and hubristic, as they claimed to have total knowledge of the natural world, and the ability to control it. As Berlin (1980: 20) has noted, Vico believed that those who were 
trying to 'prove that God exists a priori are guilty of impious curiosity. For to do that is tantamount to making oneself the god of God, thereby denying the God one seeks.' There was a collectivism and reverential piety in Vico, ${ }^{4}$ and a skepticism about some of the individualist Protestant claims, such as getting rid of all the sacred texts and practices received through tradition. Protestant intellectuals also tended to portray individual self-interest as undergirding all of human nature, and built their theories on this premise, which Vico did not agree with. Thus piety permeates his work, and works to limit history, because providence guides history, although it is not clear whether God is immanent or transcendent (Mali 1992). According to Karl-Otto Apel, Vico was in many ways the 'owl of Minerva of Renaissance humanistic culture' (quoted in Verne 1981: 26).

And yet, Vico was not a traditional classicist who wanted to continue along the same lines despite the new ideas being generated by Protestant thinkers in England, France, Germany, and elsewhere. He wanted to incorporate some of these ideas so as to 'reform' classicist thinking and carve out new, 'innovative', non-Cartesian spaces, which he saw as more scientific and rational. Vico wanted to mediate, as Joseph Levine (1991) has put it, between thinkers across temporalities, and bring the modern to bear in reading the ancients by combining philosophy and philology. As David Ingram (2007: 202) argues, Vico did not doubt 'the view that reason is the crowning achievement of human evolution'. He greatly admired some of those ideas, especially those of Protestant figures like Grotius and Bacon. He appreciated the systematic rationality of their ideas, and the importance of new scientific methods in studying humankind. He believed, for instance, that critical judgments should not be passed based only on sense experience, but that philological scientific methods were also necessary (Pompa 1971).

What Vico did not agree with, however, was the Protestant philosophers' emphasis on human nature as fixed and unchanging, as in the natural law theories of Grotius, because he believed these theories were built on false premises. Starting with flawed assumptions would yield an inaccurate picture of social reality. He disagreed with the Cartesian notion that knowledge of the physical world can be obtained through rational scientific study, because he believed this to be the domain of the divine. As Avis has noted: 'Descartes has laid down the cogito ergo sum as a self-evident truth... To this, Vico opposes another supposedly self-evident truth: we can know only what we have made: "the criterion and rule of the true is to have made it"' (1986: 138). Thus, in Descartes's famous verum factum principle, humans can only know what they have made, ${ }^{5}$ so Vico also thought that Descartes began with a false assumption. Humans can know what they have made (i.e., the social world), but not through the traditional ways of knowing. He was, for instance, dissatisfied with the traditional way of seeing myths as allegories. ${ }^{6}$

In retaining some classicist ideas, but drawing on some new ones, Vico was convinced that he had discovered a new method for understanding the social world of humans, the only world that could be known rationally. Hence, what was needed was to bring new scientific ideas into the study of history - the only realm that humans could understand in a systematic way. This was the raison d'être of the New Science. Vico claimed he was trying to do to the study of human institutions what Bacon was doing to the study of natural phenomena (Fahey 2006: 78). The method he was introducing was to study humans as 
historical beings, placing them in their historical context, and examining their origins and development as social beings.

What the contemporary thinkers (Grotius, Descartes, Locke, Hobbes) lacked were ideas of historicity - that humans should be understood as creatures of their time, and not as unchanging beings fixed in time and space. Humans developed through time in different ways in different locales, and the only way to study this was to study the stories they told about themselves. The importance of stories or myths for Vico comes from his poetic background, unlike Descartes, who ridiculed poetry and poetic wisdom; these stories would yield truths about their lives, ideas, practices, institutions, and what Raymond Williams would later call 'structures of feelings'. It was Vico's methodological contributions that were so distinctive in providing an alternative to 'the epistemological crisis of the scientific revolution' (Garin, quoted in Tagliacozzo 1982: 95). He decried his contemporaries for eulogising the ancients as though they propounded eternal truths, when he believed that they told contingent historical truths. In the case of the ancients and their deep belief in the supernatural, Vico noted, 'Men attribute to things they do not scientifically understand the will of God' (Vico 1961 [1744]: 28-29).

In his The New Science, first published in 1725, Vico argues that ancient civilizations such as the Greeks may be understood primarily via their stories or mythologies. In other words, the myths can be decoded as 'early histories', yielding a reading of the Greek's socially constructed world. As he puts it, 'First, fables must have contained civil truths, and must therefore have been the histories of the first peoples' (Vico 1961 [1744]: 31). Here, Vico is clearly positioning myths as truths made by humans, rather than divine truths. However, for Greeks, the myths were their reality, and they did not distinguish between the world of 'history' and the world of 'myth'. The gods were living forces rather than mere objects of historical and material curiosity. In this way, Vico attempts to break with the classical understanding prevalent even in his time, and develop a new way of looking at the past - as social history. For Vico, since humans make their own history, they can also understand the past through human reason:

For the first indubitable principle has been certainly been made by men, and its guise must therefore be found within the modifications of our own human mind. And history cannot be more certain than when he who creates the thing also narrates them (Vico 1961 [1725]: 62-63).

Vico tries to find the 'material' reality behind the myths. In other words, the myths cannot not be read as truth-tales in themselves; there has to be a rational and material explanation, suitable to their social and historical context. For instance, Vico mentions the barbaric way in which the Greek goddess Minerva was born (by Vulcan splitting Jove's forehead with an axe) with some disapproval. Vulcan, he argues, represented the servile classes, or famuli, which challenged the rule of Jove. Jove's rule had become monarchical, and those challenging it wanted to transform it into a city-state system under aristocratic rule. 'Hence it is not an unlikely conjecture that Minerva's name was derived from minuere... in the sense of change of state, as Minerva changed the family-state to the city-state' 
(Vico 1961[1744]: 172). And: ...the famuli merged to form the first plebs of the heroic cities, in which they had none of the privileges of citizenship (Vico 1961[1744]: 176).

Vico reads these myths as reflecting the social transformations taking place in Greek society. In this view, the origins of civilization lie in the attempt by commoners or plebeians to gain access to privileged parts of the cities. This led to social conflicts, but the commoners continued to push for equal civil rights under the law, thereby making the political system more egalitarian (Avis 1986: 244). Even in the ancient past, the plebeians always sought to change the form of government and abolish oppression, while the nobles always sought to retain their privileged positions, and those struggles were reflected in the Greek fables. For instance, the myth about the struggle of Hercules against Antaeus was about the 'victory of the heroes over the rebel plebeians, whom the heroes then bound to the earth with the Herculean knot as their nexi, or bondsmen' (Vico (1961\{1744]: 187). Similarly, ' $\mathrm{t}$ ] he head of Medusa with the snakes, used by Minerva to turn its beholders to stone, was the high family domains of the fathers with their power of punishment' (Vico 1961[1744]: 187).

These myths, Vico argues, reflect the ways in which the privileged nobles continued to subjugate the plebeians, while celebrating the force of the Greek gods. Hence, he writes, 'By singing to the Greek plebs of the force of the gods in the auspices ... they kept the plebs in subjection to their heroic orders' (Vico 1961 [1744]: 200-201). However, unlike the belief in progress by later, historically minded thinkers who drew on Vico, the latter points out that as modern people began to move away from the mytho-poetic imagination, they became more corrupt, and institutions began to decline (Avis 1986: 245). Like Nietzsche later, Vico bemoans the decline of the poetic imagination, but unlike Nietzsche, he does not decry the use of reason in his own time. ${ }^{7}$

Vico classifies human history intro three epochs, taken from the ancient Egyptians: the Age of Gods, the Age of Heroes, and the Age of Men. According to Vico (1961), the first two ages were essentially poetic, and 'lacked reflection'. Ancient people create gods due to a fear of the unknown: 'Greeks had gods to the number of 30,000 as they made everything a deity including stones, springs, plants, rocks, etc' (Vico 1961 [1744]: 102), which indicated a 'childlike imagination'. These ancient people were like children who could not form 'intelligible class concepts of things', and so ended up relying on the imagination (Vico 1961[1744]: 32). Children, he suggests, are best at imitating, and 'poetry is nothing but imitation'; hence, early people were the 'children' of the human race' (Vico 1961[1744]: 33).

Phule is actually far more strident than Vico about the irrationality of ancient myths, and finds little poetic value in them. He sees them as too fantastic to be true and, unlike Vico, is far less sympathetic towards them. For instance, Phule views ancient Krishna stories with great skepticism, pointing out that Krishna's lifting of Govardhan Mountain to save his people or his jumping into the Yamuna River to battle an enormous serpent were essentially incredible (Phadke 1992: 469). While Vico also believed that Greek myths belonged in the realm of fantasy, he regarded their poetic imagination as admirable.

Phule believed that ancient Hindu myths reflected social relations that needed to be demystified and exposed for what they truly signified. Like Vico, he attempts to uncov- 
er the material realities behind the myths, and reads them as social histories indicating struggles between the dominant groups (Brahmins) and commoners (lower castes): 'From many customs traditionally handed down to us, as well as from the mythological legends contained in the sacred books of the Brahmins, it is evident that there has been a hard struggle for ascendancy between the two races' (Phule 1992: 118-119).

Since Brahmins held power, they deliberately wrote these stories legitimising their gods in order to conceal their dominance. Thus for Phule, popular memories such as the Hindu myths handed down for generations were nothing but stories that reflected, to use Vichian terms, 'common sense' masquerading as 'religious truths' in service of the dominant castes. For Phule, like Vico, since history is human-made and reflects human struggle, social conditions can be changed, and there is nothing fixed or eternal about history. While neither thinker rejects the presence of divine forces or religion altogether, they share the belief that history is human-made, that humans are the primary agents of history, and that collective change can be brought about through an awareness of the 'truth' of history. Of course, Phule was far more political than Vico. His approach to history reflected an explicit political agenda, whereas Vico was more interested in looking at history for its 'own sake'.

Vico was interested in the minute details of the past, and the distinctive characteristics of each age: 'Peoples have acquired diverse natures and cultural characteristics through being exposed to different climates which have in turn influenced customs and even languages' (Vico 1961, cited in Avis 1986: 155).

In his writings, Phule demystified numerous ancient Hindu myths. Like Vico, he looked for their historical origins, and retold them for what he believed they really were, namely stories of power, control and domination. In his well-known book Gulamgiri or Slavery (Phadke 1992: 109-192), he discusses several dominant myths about the reincarnation of Lord Vishnu. Parts of Phule's text are set up as conversations between himself and a man named Dhondiba. The latter asks questions, and Phule provides rational and historical explanations with the aim of educating the 'audience' that is reading or listening. Phule argues that the Aryan-blooded Brahmins originally came from Iran and conquered the indigenous peoples, turning their victims into lower castes (Shudras) and untouchables (ati-Shudras). It is these Brahminical victories, such as the myths regarding Vishnu's various incarnations, that he believes are chronicled as early mythologies intertwined with divinity.

The first incarnation of Vishnu is as Matsya, a fish. According to Phule, it is likely that the Aryan Brahmins came to western India by sea in boats, and their chief was probably called Matsya (fish). Matsya and his people attacked a local chieftain called Shankhasur, and took his kingdom. In the early myths, he points out, Shankhasur is portrayed as a rakshas, or demon, while all the local people who fought the Brahmins are characterised as demons. Another incarnation of Vishnu was Narsimha, half-man and half-lion. Phule ridicules the possibility that such a creature could ever exist. In the original story, as recorded in the puranas, ${ }^{8}$ Narsimha arrives as an avatar or incarnation of Vishnu in order to defeat the cruel and unjust demon Hiranyakashyapu. In the Bhagvat Puran, Hiranyakashyapu, the twin brother of Hiryanya, is a demon who, following severe austerities, is given a boon 
by Lord Brahma that no animal or human would ever kill him. As I have discussed elsewhere, ${ }^{9}$ in the Bhagvat Puran, Hiranyakashyapu, the twin brother of Hiryanya, is a demon who, following severe austerities, is given a boon by Lord Brahma that no animal or human would ever kill him. Once powerful he starts terrorizing people and becomes very corrupt. He violates the shastras or the religious codes. He attempts to kill his son Prahlad who is Vishnu's devotee. Vishnu in turn tells Prahlad he can ask for any boon he wishes as he is impressed with his devotion. Prahlad asks that his father's weapons be taken away as the latter repeatedly tries to kill him. Vishnu comes in the form of Narsimha (half man, half animal) and attacks Hiranyakashyapu, slaying the demon. The Gods reward Prahlad for his devotion to Vishnu.

In reality, Phule writes, Hiryanyakashyapu was a great Kshatriya (warrior caste) ruler who challenged Brahminical Aryan dominance. Narsimha manipulated Prahlad and turned him against his father so that Hiryanyakashyapu could be defeated. What actually happened, according to Phule, was that Narsimha dressed up as a lion, and waited for Hiryanyakashyapu to arrive. Narsimha attacked him while the ruler was resting. He ripped his stomach open using his claws, killing him instantly. Narsimha ran away and never returned. According to Phule, as the demon challenged Brahminical authority and did not follow their social norms he was written into the myth as 'evil'.

Phule adds an incarnation that is not there in the puranic myths, that of Lord Brahma, from whose mouth the myths suggest all knowledge originated, including the vedas, puranas, itihasas (epics such as the Ramayana), shastras (scriptures), and the four-fold varna, or caste system. Similarly, as I have argued, ${ }^{10}$ the origins of the word Brahmin Phule argues, came from the name 'Brahma, who rather than being a divine being and the origin of all creation was in fact merely a small-time Brahmin official who became their leader. Like Vico, he focuses on words and language to look at the possible origins of certain practices. However, Vico undertakes the use of etymology in a far more systematic and scholarly manner, whereas Phule's is more speculative. According to Phule, Brahma who is known to have four faces in Hindu myths was actually four-faced in behavior or treacherous. He fabricated myths and legends that were widely popularized and ignorant people began to believe these originated from his own mouth. Phule points to a present-day custom in his time of the prohibition of non-Brahmins from chanting a mantra known as the gayatri mantra ${ }^{11}$ which he argues, originates with Brahma teaching this only to the Brahmins so that if they were attacked they would share it only amongst themselves. Moreover, another custom of Brahmins tying a white thread across their chest also originates with Brahma so that he could identify his people.

Once Brahma had defeated the local 'demon' kings, Phule tells Dhondiba, he enslaved the local people. This is how the local Kshatriyas (warriors) became Shudras, serving Brahmins and doing all the lowly tasks. Phule traces the origins of the practice of untouchability to the defeat of these local people termed maharis (great enemies) by Brahmins. He says, the present term for untouchables or mahars comes from the humiliation of the maharis. Once they were defeated the Brahmins Phule points out, would not drink or eat with the Mahars or allow them to touch them. Furthermore, they would not look at manual labor favorably and looked down upon all those who worked on the lands. The 
Brahmins themselves, Phule says, would not do any of their own menial tasks such as agricultural related activity and wrote their prejudices into their books characterizing these tasks as defiling human beings. Their books were also restricted to their own community while the lower castes were kept illiterate thanks to religious codes that did not allow them to read. According to Phule, this is how Brahma created the caste system and ensured that Brahmins remained dominant.

Phule uses the past more instrumentally than Vico for an explicit political purpose in the present: to question the caste system by exploring its origins and development. This establishes caste as a historical process that developed over time rather than being rooted in an eternal Hindu tradition; therefore, it is also subject to change. Vico, on the other hand, wanted to understand the past for its own sake, and saw it as quite different from the present, with its own value and worth. He had an intellectual curiosity and interest in ancient societies, which for him were quite unique and distinct from the modern. According to Vico, one could not use a 'presentist' lens, or let contemporary prejudices colour the study of the past. Ancient societies, for Vico, laid the foundation for many of the social customs and practices that were found in his present, as reflected in language. Therefore, Vico is driven primarily by historical curiosity even if he turns to the past to intervene in the debates of his times. The distinctiveness and separateness of the past has to be maintained. For Phule, there is no other way of viewing the past but through the prism of the present; if this is implicit in Vico, it is explicit in Phule, because history is inextricably linked to politics. ${ }^{12}$

\section{The limits of history}

Despite Phule's skepticism about the veracity of ancient myths and their poetic imagination, he dips into them in order to plot their narratives in a different way. He does this by drawing on the popular folk customs and practices in his region (western India, or today's Maharashtra). While Vico, like Phule, deconstructs these myths in order to expose their materiality, he also bemoans the fact that people in his time lack the poetic imagination to recreate such myths, which reflect the fantastic and the supernatural, and elicit a sense of awe, wonder and fear. It is a world he thinks modern people can no longer inhabit. As Ingram (2007: 202) suggests, Vico sees his own times as based on Reason, and therefore enlightened, and yet - anticipating Nietzsche, Weber and Rousseau - he believes too much civilization leads to decay.

Phule is able to draw effortlessly on a peasant cosmology filled with myths because they are an integral part of society, tied to people's everyday lives. For Vico, the Roman and Greek legends are increasingly viewed in historical terms, belonging to a separate time in human history. Phule draws on the Bali myth (discussed in greater detail below), a popular legend tied to the religious world views of the peasant castes in his region. The Bali myth is common to both upper and lower castes in the region, but with radically different readings. While Phule seeks to unearth the historical origins as well as the social and material meaning of this popular myth, and thereby demystifying it, he also draws on dissenting folk versions to construct alternative mythologies for the peasant and subaltern 
castes of his time. He fabricates new kinds of stories and legends, drawing on common oral and written narratives, and attempts to popularise these among the peasantry. $\mathrm{He}$ writes mainly for a non-literate, non-Brahmin audience, which is perhaps why he turned to popular forms such as abhangs (short poems), powadas (ballads), plays, and stories that can be shared orally, as was often the case. Many of his views were expounded through conversations between himself and a friend or his son, reminiscent of conversations in the many legends and myths he criticizes so vehemently. The notion of an 'objective' history separate from its location and politics has little use for him.

This is why it was important for Phule to appropriate certain important mythological figures whom, as he points out, represent lower-caste, non-Brahminic or Shudra pride and heritage. One mythological figure that Phule chooses is the demon-king Bali. In many cases, those regarded as demons or evil in the various myths and epics are revered figures among lower castes as well as tribal and other marginal groups. Phule suggests that reverence for certain demons in these popular memories points to the silencing of lower caste counter-narratives in these dominant myths. This is not uncommon in India, even today. For instance, the Gond tribals of Maharashtra revere Ravana, the evil demon king in the popular epic Ramayana, and celebrate his life during the annual Dussehra festival, while others use this day to celebrate his defeat by Lord Rama as part of the triumph of good over evil (Rashid 2015).

\section{Myths about Bali, the demon-king}

One of Vishnu's many incarnations is the dwarf Vamana who defeats the demon-king Bali in a popular puranic myth. Phule gives a lot of importance to this myth because it is deeply embedded in the folklore of his region. In Gulamgiri, he attempts to find a rational and historical explanation for the myth, but also goes on to retell it by drawing on the various interpretations he is familiar with among the peasant castes of the region. In Marathi folklore, Bali is a heroic peasant-king. There were many practices for remembering Bali during Phule's time, including the festival of Diwali, when women would lay out mounds of cow dung in the front of their homes and worship them, referring to them as King Bali and his consorts (Chousalkar 1991: 78). Similarly, women remember Bali ${ }^{13}$ during the festival of Raksha bandhan, when a sister ties a rakheeor, or string, around her brother's hand and he swears to protect her. Phule also draws on local, non-Brahiminic gods intricately tied to the geography of the region, weaving them into his narrative about Bali.

\section{The Puranic version of Bali, the demon-king}

I have discussed the Bali myth elsewhere in my discussion on Phule. ${ }^{14}$ I reintroduce it here in order to examine how Phule historicizes myths and then goes on to rewrite them in relation to Vico. This rewriting is most evident in his use of the Bali myth. Phule responds to the well-known Bali story found in the Bhagvat Puran in Hindu mythology. ${ }^{15}$ In the Puranic rendition, Bali, the great-grandson of Hiryanyakashyapu, whom we have met 
before (who was slain by Narsimha) is considered a great ruler for his many benevolent virtues. He is most well known for his generosity. As he is the follower of the Brahmins of the Brgu race they bring him back to life once Lord Indra defeats him and honour him with a sacrifice that makes his just as powerful as Lord Indra. Bali is successful in his subsequent battles with Indra, who realizes he cannot defeat his enemy unless Bali is made to turn against the Bhrgu Brahmins. In other words, Indra has to create a situation where Bali insults or humiliates his mentors. Bali enjoying the support of the Bhrgus becomes practically invincible in his power and glory and is also a popular ruler amongst his people.

The gods were concerned about Bali's rise, and hence Vaman the dwarf was born as one of the Vishnu's incarnations in order to defeat Bali and restore cosmic balance. Vaman comes as a Brahman, as Bali's guest and knowing that Bali is very generous makes a request. Bali in turn is very respectful towards him and is well known for his hospitality. He tells Vaman he can ask for anything he wants. Vaman first praises Bali (and his grandfather Prahlad) and asks him for a small piece of land that would equal his own three strides. Bali who is known to never insult a guest readily agrees. His mentors the Bhrgus recognize that Vaman is actually Vishnu who has come to defeat Bali and try to warn him. They advise him to reject Vaman's request as self-preservation, they point out, is more important. But for Bali principles come first. He cannot break a promise he has made to his guest. The Bhrgu sage Sukracharya feels insulted as Bali spurns his advice and curses him enabling his

Once Bali agrees to Vaman's request, Vaman the dwarf transforms into a giant and takes three strides. His first stride covers the earth and sky, while the second, the heavens. Vaman asks Bali where he can take his third stride as he has covered all the three worlds of earth, heaven and sky. Bali who is bound up in cords, offers that Vaman can take the third or last stride on his head. Vidhyavali, Bali's wife pleads with Vaman to spare her husband but he ignores her requests. Vaman declares that Bali's defeat is inevitable and necessary but recognizes that Bali is courageous and generous; thus, he grants him a concession that Bali will upon his death ultimately go to heaven and take the form of Indra later but until that time will have to live in the subterranean region of Sutala. In this manner, the Puranas suggest, Vaman restores the cosmic order by giving the heavens back to Lord Indra and satisfying his mother, Aditi.

The puranas are also ambivalent about Bali, who is seen as a loyal, brave and generous ruler. The fact that the gods played some dirty tricks is acknowledged in the story. Also Vaman's, or Vishnu's, promise to Bali that he would become a god at a later time and also be remembered by people at certain times of the year, such as the annual Onam festival in the southern Indian state of Kerala, is a concession to and recognition of Bali's greatness. Yet, since he is a demon, despite all his benevolence and generosity, his fate is doomed, and he cannot defeat the gods. In Phule's rendition, which he partly draws from the folk stories, he imagines an inversion in which Bali is the divine 'Shudra' king whose son is able to take revenge for Bali's defeat. 


\section{Phule's rationalising and re-telling of the Bali myth}

Phule's retelling portrays Vaman and Bali as real historical figures who fought battles over what he calls Balisthan, or India, although Phule is referring largely to the Marathi-speaking region. As Phule suggests, Vaman is in reality the leader of the Brahmins or Aryan conquerors from Iran who wanted to defeat Bali, known to be a very popular ruler. Phule writes, Bali divided his kingdom into nine khandas or parts and gave each part to a revenue officer named Khandoba. He traces the origins of the name 'Khandoba' to Bali's time. Khandoba is actually a popular folk deity even in contemporary Maharashtra amongst the peasantry. His shrine is located in a place called Jezuri where thousands of people visit especially during harvesting season and important agricultural cycles. Phule argues that these popular folk deities were likely leaders who fought on Bali's side against the invading Aryan Brahmins.

Phule (1992: 151) takes a popular Marathi folk saying, 'Bali toch kan pili' ('Bali, he is the one who will wring your ears'), and reads it as historical evidence of Bali's greatness among the lower castes. In Phule's version of the story, Vaman along with his people the Aryans led a battle against Bali which lasted 15 days. They aimed to defeat Bali and usurp his territories. According to Phule, Bali's Vindhyawati abstained from eating or drinking for eight nights and days while the battle raged and prayed for Bali's victory. When she heard Bali had fallen she dug a pit, placed wood in it, lit the fire and walked into it, becoming a sati. ${ }^{16}$ Both Bali and his son Banasura were defeated by Vaman's forces who destroyed Bali's capital and took away all his gold. Phule writes, Vaman returned home victorious after defeating Bali and kicked the latter's effigy which his wife had placed when he entered his home telling him Bali had returned to fight. The social custom in Phule's time of making Bali's effigies with rice grains or flour, keeping them at the door and then kicking them when entering the home during the festival of Dussehra in Brahmin homes likely he argues, originates here. Thus, he says, Brahmins continuously reenact Bali's defeat.

Amongst non-Brahmin or lower caste families the ritual of remembering Bali is very different. Phule tells us that here the wives light lamps, circle them around their husbands when they come home and declare "Let troubles and sorrows vanish, with the power of the twice-born and Bali's rule come back" (Phule 1992:153). According to him, this likely originated when Banasura and his followers went home after defeating Vaman and their wives kept symbolic Balis at the door and declared that Bali's rule would come back. However, in Phule's version, unlike the puranic one, Banasura was able to recoup his forces and defeat Vaman. Phule therefore provides a different interpretation of the Bali story from that described in the puranas. It is of course a story that he fabricates and not one based on any historical evidence; rather he roots it in the social customs and practices of his time.

Even if Vico does not go as far as Phule in transgressing history, there are limits to history in his writings. Vico does introduce modern ideas of human development through secular time, and emphasises human agency, historical context (the separateness of past and present), the social constructedness of knowledge, and human capacity to bring about collective change. Even so, he also retains certain classical ideas that act as 'checks' on 
the totalising claims of humans and history, which is precisely what he was ambivalent about with respect to the Cartesian arrogance about human nature. Unlike later ideas of historical teleology, history for Vico does not move in any particular direction, but rather between reason and unreason (Maier 1976: 854). However, later thinkers who implicitly drew on Vico's ideas (Marx comes to mind) remove the transcendental aspects of his thought, bring in notions of progress, and end up with a totalising view of humans and history in which only humans can know and control the world, and do so historically. Even non-Marxists and non-Hegelians who later drew on Vico tend to downplay the transcendental aspects of his work. This trend continues in post-modern readings. While post-modernists appreciate Vico, they cannot incorporate his views on the role of God into their own thought, since post-modernism is fundamentally secular.

Therefore, the most important idea that acts as a check on or limit to history in Vico's writings is that of providence. This is a complicated and relatively unclear notion, since Vico is seeking to find a balance between human agency and the role of divine purpose. While he wants to acknowledge total human agency in the making of history, providence works through humans, and acts as a kind of guiding force. It shapes, according to Vico, 'our lives against our conscious purposes; but it is our desires, our goals, our motives, our acts, through which it works its will' (Berlin 1980: 52). Vico sees providence as the movement of human history towards its own ideality. According to Caponigri (1953: 133), Vico's notion of providence 'denominates ... a movement within the life of the nation by which that life is lifted and advanced in ideality at the same time it retreats upon itself'. This is then tied to his idea of corsi e ricorsi, or the cyclical notion of time. Movement is not linear, but patterns repeat themselves not at the level of a material repetition but at the level of ideas (Caponigri 1953). New life will spring from old not by deliberate human design, but by humans following God (Berlin 1980). While humans may make their own history, providence works through them, since the human mind perceives the divine mind (Mali 1992). Vico referred to his approach as a 'rational secular theology', thus trying to find a synthesis between the ancient and the modern.

One of the most significant implications of Vico's idea of providence is that it limits the capacity of humans to know and control the natural world, and limits human knowledge: 'Man is not nothing nor everything' (Vico 1710, cited in Lila 1993: 37). According to Lila (1993: 37), Vico sought to restore in humans 'the prudence and moderation of an earlier age. Thus, the notions of providence and cyclical time are remnants of classicism that allow Vico to retain a sacral or non-secular world view.

However, the tension between asserting and undermining a religious perspective seem to lie within Vico himself, whether he anticipated this contradiction or not. Placing humans in their historical context makes the past primarily and 'legitimately' accessible through history, philology, etymology, archaeology, the study of antiquities, and so on, and also paves the way for historicism as practised by Marx, Hegel and the German historicists. ${ }^{17}$ Ironically, the 'traditional' Catholic Vico ended up undermining the 'eternal religious truths' on which traditional Catholicism was based by introducing a historical perspective. Catholicism, or any religion for that matter, could not remain the same once 
it came under the historical gaze. In the process, Vico inadvertently contributed to the 'age of skepticism' about which he was so ambivalent. The same was true for the study of myths, the forms of knowledge and 'truth' that Vico revered so greatly.

\section{Conclusion}

Both Vico and Phule historicised the past in order to question the essentialisms of their times. Both were interested in uncovering the origins of certain ideas and practices, and focused on words and language to do so. By rationalising myths, they attempted to uncover what these myths could say about relations of dominance and control as well as dissent, thus anticipating social constructivism and Marxian/Gramscian ideas of dominance and hegemony. In the process, they pointed to the constantly changing nature of human society and the capacity for collective human agency to effect change. Both saw themselves as introducing new ways of viewing the past, time, and human agency, and as breaking with tradition even if they were embedded within them. Vico was not entirely comfortable with classicism, and deeply dissatisfied with new notions of the 'eternal' nature of ideas, and turned to history as a critical way to show alternatives. Phule was strident in his critique of Brahminism, and adopted a historical perspective as the most rational and legitimate way of addressing contemporary social injustices. Interestingly, one can find limits to history in both Phule, through his story-telling, and Vico, through his ideas of providence and cyclical time.

Phule went further than Vico in his transgression of historical time by retelling stories or myths drawn from regional folklore, thereby temporally co-inhabiting these myths rather than relegating them to the past. While Vico rehabilitated their importance, and uncovered their beauty, he could not co-habit them in the same way. Following Joseph Mali, I have argued that this difference between the two scholars arose because Vico's milieu distanced him from myths in ways that did not apply to Phule. Hence discussing Phule, who was located in a different cultural context than Vico, but shared many of his ideas, would extend the debate on history, temporality and myth even further.

\section{Notes}

1 Giambattista Vico (1668-1744) was a professor of rhetoric in Naples, Italy. He was not well known in his own lifetime, and endured poverty and hardship.

2 Joseph Mali (1992: 2) argues that many of the ideas Vico has been made to advocate were not ones he would have conceived himself. Donald P Verne (1981: 23) argues along similar lines that people have been reading what they want to read with respect to Vico's writings.

3 Phule (1827-1890) belonged to the peasantry, more specifically the mali or gardener caste (considered a lower caste). He was exposed to western education through a Scottish mission school, and therefore read and wrote fluently in English. He was a major social reformer who argued strongly against caste, supported women's emancipation, and worked as a farmer/contractor.

4 This piety, Mali (1992) notes, comes from Vico's traditional Catholic background. Vico ends The New Science with the following statement: 'It is to be finally concluded that this science carries inseparably with it the study of piety, and that he who is not pious cannot be truly wise (Vico 1961: 384). 
5 Perez Zagorin (1984) points out that the verum factum principle was not unique to Vico, but was also recognised by Hobbes and Locke, although neither thought of applying it to history.

6 Mali (1992: 140) notes that Bacon was the last in the line of scholars who read myths allegorically, a long and unbroken tradition from antiquity to the Renaissance and beyond. Vico wanted to break from this tradition even though he admired Bacon.

7 Moreover, unlike Nietzsche, Vico was less pessimistic, and believed in the value of social existence (Luft 146). This may have come from his belief in God, about which Nietzsche was far more skeptical.

8 The puranas are ancient Sanskrit texts dating back to the fourth century, which deal with creation myths as well as legends about gods and demons and are considered part of popular Hindu religion in comparison to the more classical Brahminical metaphysical texts, the Upanishads and Vedas. There are 18 puranas in total.

9 See Devare (2011: 67).

10 See Devare (2011: 68).

11 A vedicmantra (vedic hymn) that Brahmins have historically claimed only they can recite.

12 Phule is using the myths instrumentally for political purposes, which is different from how his predecessors might have used them, since he is intervening in a modern public sphere. I owe this point to Sanjay Srivastava (personal communication, 2 November 2015).

13 Kunbis are called Bali, meaning possessing strength (O’Hanlon 1985: 153).

14 See Devare (2011: 75-80).

15 The puranic Bali story is drawn from the Srimad Bhagavata Mahapurana (Goswami 1971: 885-933).

16 Sati is a practice in which women immolated themselves on their husbands' funeral pyres. It was prevalent especially in Hindu warrior communities, but was officially banned in 1861 .

17 Timothy Brennan (2014: 20) sees Vico as a precursor to Marx in anticipating his historical materialism. Cecilia Miller (1996) also discusses the many similarities between Marx and Vico, but notes that Vico would not agree with Marx in many other respects. This discussion falls outside the scope of this paper.

\section{References}

Avis, Paul. 1986. Foundations of Modern Historical Thought: from Machiavelli to Vico. LondonSydney-Dover-New Hampshire: Croom Helm.

Berlin, Isaiah. 1980. Vico and Herder: Two Studies in the History of Ideas. London: Chatto and Windus.

Brennan, Timothy. 2014. Borrowed Light: Vico, Hegel and the Colonies. Stanford: Stanford University Press.

Caponigri, Robert A. 1953. Time and Idea: The Theory of History in Giambattista Vico. Notre Dame and London: University of Notre Dame Press

Chousalkar, Ashok. 1991. 'Mahatma Phuley and the myth of Baliraja'. Paper produced for conference entitled 'Jotiba Phule: An Incomplete Renaissance'. Surat: Centre for Social Studies. 75-86.

Devare, Aparna. 2011. History and the Making of a Modern Hindu Self. London, New York, New Delhi: Routledge.

Fahey, Michael W Anthony. 2006. 'Vico's Road to Postmodernism'. Master's thesis, National University of Ireland Maynooth.

Goswami, C L. 1971. Srimad Bhagavata Mahapurana (Eight Volumes). Gorakhpur: Gita Press.

Hutton, Patrick. 1996. 'Vico and the end of history'. Historical Reflections/Reflexions Historiques, 22(3): 537-558. 
Ingram, David. 2007. 'Vico's new science of interpretation: beyond philosophical hermeneutics and the hermeneutics of suspicion'. In Pol Vandevelde (ed), Issues in Interpretation Theory. Milwaukee, Wisconsin: Marquette University Press. 199-223.

Levine, Joseph. 1991. 'Giambattista Vico and the quarrel between the Ancients and the Moderns'. Journal of the History of Ideas 52(1): 55-79.

Lila, Mark. 1993. 'G B Vico: The antimodernist'. The Wilson Quarterly 17(3): 32-39.

Luft, Sandra Rudrick. 2003. Vico's Uncanny Humanism. Ithaca: Cornell University Press. 1994. 'The secularization of origins in Vico and Nietzsche'. The Personalist Forum 10(2): 133-148.

Maier, Joseph. 1976. 'Vico and critical theory', Social Research 43(4): 845-856.

Mali, Joseph. 1992. The Rehabilitation of Myth: Vico's New Science. Cambridge: Cambridge University Press.

Miller, Cecilia. 1996. 'Interpretations and misinterpretations of Vico'. Historical Reflections/Reflexions Historiques, 2(3): 619-639.

Miner, Robert C. 2002. Vico - Genealogist of Modernity. Notre Dame: University of Notre Dame Press.

O’Hanlon, Rosalind. 1985. Caste, Conflict and Ideology: Mahatma Jotirao Phule and Low Caste Protest in Nineteenth-Century Western India. Cambridge: Cambridge University Press.

Phadke, Y D (ed). 1992. The Collected Writings of Mahatma Phule [Mahatma Phuley Samagra Vangmay]. Fifth Edition. Mumbai: Maharashtra Rajya Sahitya ani Sanskruti Mandal.

Pompa, Leon. 1971. 'Vico's Science'. History and Theory 10(1): 49-83.

Rashid, Omar. 2015. 'Celebrating Ravan'. The Hindu [online]. Available at http://www.thehindu. com/features/magazine/omar-rashid-on-ravan-worship/article7799972.ece [accessed on 1 December 2015].

Renger, Almut-Barbara. 2014. 'Between history and reason: Giambattista Vico and the promise of classical myth'. Journal of Cultural and Religious Theory, 14(1): 38-52.

Spiegel, Gabrielle. 2002. 'Memory and history: liturgical time and historical time'. History and Theory 41: 149-162.

Verne, Donald P. 1981. Vico's New Science: A Philosophical Commentary. Ithaca and London: Cornell University Press.

Tagliacozzo, Giorgio. 1982. 'Vico: a philosopher of the eighteenth and twentieth century'. Italica, 59(2): 93-108.

Vico, Giambattista. 1961 [1744]. The New Science of Giambattista Vico. Translated by Thomas Goddard Bergin and Max Harold Fisch. New York: Anchor Books.

Yerushalmi, Yosef Hayim. 1982. Zakhor: Jewish History and Jewish Memory. Seattle and London: University of Washington Press.

Zagorin, Perez. 1984. 'Vico's theory of knowledge: a critique'. The Philosophical Quarterly, 34(134):1530. 


\section{Acknowledgements}

I would like to thank A Raghuramaraju and Naren Kumarakulasingam for their close reading of the article and for asking the important 'why' questions. I am also grateful to the Centre for the Study of Social Systems at Jawaharlal Nehru University (New Delhi), especially Ratheesh Kumar, for giving me the opportunity to present an early version of this article. The feedback from faculty and students present was very useful. I am also thankful to the anonymous reviewers for their comments. Last but not least, I greatly appreciate the help rendered by my research assistant, Sreejoni Saha.

\section{About the author}

Aparna Devare is an assistant professor of political science at the University of Hyderabad, India. She is the author of History and the Making of a Modern Hindu Self (Routledge 2011). The book examines visions of three Indian thinkers, Ranade, Phule and Savarkar, and their negotiation with history and colonial modernity. She has also published articles in journals such as International Political Sociology and Postcolonial Studies. She teaches and researches in post-colonial studies, international relations theory and global politics, religion and politics, and Indian political thought. Her current research uses non-western political thinkers and concepts to interrogate dominant frameworks in international relations.

Received on 4 January 2016, and approved for publication on 12 July 2016.

\section{(cc) BY-NC} https://creativecommons.org/licenses/by-nc/4.0/ 